\title{
Changes in the suppressive effects of recombinant inhibin A on FSH secretion in ram lambs during sexual maturation: evidence for alterations in the clearance rate of inhibin
}

\author{
A J Tilbrook ${ }^{1}$, D M de Kretser ${ }^{2}$ and I J Clarke ${ }^{3}$ \\ ${ }^{1}$ Department of Physiology, Monash University, Clayton, Victoria 3168, Australia \\ ${ }^{2}$ Institute of Reproduction and Development, Monash University, Clayton, Victoria 3168, Australia \\ ${ }^{3}$ Prince Henry's Institute of Medical Research, Clayton, Victoria 3168, Australia \\ (Requests for offprints should be addressed to A J Tilbrook)
}

\begin{abstract}
We have investigated the effectiveness of human recombinant inhibin $\mathrm{A}$ (hr-inhibin A) to suppress the secretion of follicle-stimulating hormone (FSH) in ram lambs from 1 to 18 months of age. Seventeen rams (nine castrated, eight intact) were used. At 1, 3, 6, 9, 12 and 18 months of age the rams were given an i.v. injection of either vehicle or hr-inhibin A $(0 \cdot 64 \mu \mathrm{g} / \mathrm{kg})$. Blood samples were taken over $24 \mathrm{~h}$. Plasma concentrations of FSH were suppressed in castrated and intact rams following injection of hr-inhibin A with maximal suppression occurring $6 \mathrm{~h}$ after injection. Vehicle injection had no effect. At 12 months of age the suppression in FSH was most rapid in castrated rams and was maximal in intact rams. The clearance rate of inhibin
\end{abstract}

was greatest at older ages but during the period of seasonally induced testicular activity, there was a significant decrease in the inhibin clearance. The testicular weight was reduced in rams treated with hr-inhibin A, indicating the importance of FSH for testicular development during the pubertal period. There was no effect of hr-inhibin A on plasma concentrations of luteinizing hormone. We conclude that inhibin is capable of suppressing the secretion of FSH in rams from 1 month of age onwards and that the pituitary gland becomes maximally responsive to the actions of inhibin by the age of puberty.

Journal of Endocrinology (1999) 161, 219-229

\section{Introduction}

In adult males inhibin, produced principally by the testes, plays a major role in the negative feedback regulation of the secretion of follicle-stimulating hormone (FSH) at the pituitary in male Rhesus monkeys (Dubey et al. 1987, Medhamurthy et al. 1990, 1991, Attardi et al. 1992, Majumdar et al. 1995, Plant et al. 1997) and rams (Tilbrook et al. 1993a,b, McKeown et al. 1997). In contrast to adult males, the role of inhibin in the feedback regulation of FSH in prepubertal males and during sexual development has not been studied in detail. The testes of prepubertal males synthesize and secrete significant amounts of inhibin and the pattern of secretion of inhibin changes during sexual development although there appears to be substantial differences between species. For example, circulating concentrations of inhibin during sexual maturation have been found to increase in male monkeys (Keeping et al. 1990, Marson et al. 1993) and in boys (Burger et al. 1988, Crofton et al. 1997) but to decrease in male rats (Wreford et al. 1994), bulls (Miyamoto et al. 1989, MacDonald et al. 1991) and rams (Schanbacher 1988, Isaacs et al. 1995). Several studies indicate that a functional negative feedback system between inhibin and FSH exists before puberty as shown by the decrease in plasma concentrations of inhibin and an increase in FSH in 1-week-old ram lambs (Schanbacher 1988), and the demonstration that active immunization against inhibin in prepubertal ram lambs (Al-Obaidi et al. 1987) and bull calves (Martin et al. 1991, Schanbacher 1991) caused an increase in plasma concentrations of FSH.

Interpretation of the physiological significance of the role of inhibin from changes in circulating levels during sexual development may be misleading because such measurements do not take into account possible changes in the sensitivity of the pituitary gland to the actions of inhibin, in the metabolic clearance rate of inhibin and in the biopotency of inhibin. Each of these factors has the potential to influence the effectiveness of inhibin to regulate the secretion of FSH. There are only limited data in which the ability of inhibin to suppress FSH has been assessed over an age range encompassing sexual maturation. In a study designed to address these issues, intact male rats were given a single injection of human recombinant inhibin A (hr-inhibin A) which caused a significant decrease in serum concentrations of FSH measured $6 \mathrm{~h}$ 
later in animals aged 25-91 days of age but had no effect on FSH in younger animals (Wreford et al. 1994). Nevertheless, this study was limited by an insufficient sampling regimen that did not allow assessment of the time course of response of FSH to treatment with hr-inhibin A or of the clearance rate of inhibin from the blood.

In view of the observations that FSH is important for testicular development, particularly in the period immediately prior to puberty (Tilbrook et al. 1993c), and that the secretion of FSH changes during sexual development, we have tested the hypothesis that the effectiveness of inhibin to suppress the secretion of FSH varies during sexual development. To achieve this aim we have treated intact and castrated rams with hr-inhibin $\mathrm{A}$ at various ages from 1 to 18 months and report the results of these experiments on FSH secretion.

\section{Materials and Methods}

\section{Animals}

Seventeen Romney Marsh rams of the same age were used and nine were castrated at 5 days of age and the study ended when they were 18 months of age. For the sampling and treatment periods, the rams were penned individually in an animal house and given a maintenance ration and water and allowed to feed ad libitum. Between the periods of sampling and treatment the rams were grazed on natural pastures at the Victorian Institute of Animal Science, Werribee, Australia. From 1 to 3 months of age the rams were grazed with their mothers, and kept as a single group until 18 months of age.

The care and experimental use of the animals in these experiments conformed with the requirements of the Australian Prevention of Cruelty to Animals Act 1986 and the NHMRC/CSIRO/AAC 'Code of Practice for the Use of Living Animals in Scientific Investigations'.

\section{Experimental procedure}

The rams were allocated to one of the following four groups: (1) intact rams given a single intravenous (i.v.) injection of vehicle $(n=4)$, (2) intact rams given a single i.v. injection of $0.64 \mu \mathrm{g} / \mathrm{kg}$ hr-inhibin A $(n=4)$, (3) castrated rams injected i.v. with vehicle $(n=4)$, and (4) castrated rams injected i.v. with hr-inhibin A $(n=5)$. We have shown previously that this dose of hr-inhibin A is effective in suppressing the plasma concentrations of FSH to those found in normal intact rams, with maximal suppression occurring about $6 \mathrm{~h}$ after injection (Tilbrook et al. 1993a). The vehicle and hr-inhibin A were administered by venepuncture into the jugular vein at 1, 3, 6, 9, 12 and 18 months of age. Blood samples $(5 \mathrm{ml})$ were collected via indwelling jugular catheters (Dwellcath, Tuta Laboratories, Lane Cove, Australia) 20 and $10 \mathrm{~min}$ before injection and 1, 5, 10, 30 and $60 \mathrm{~min}$ and 3, 6, 12 and $24 \mathrm{~h}$ after injection. The blood samples were assayed for FSH, inhibin and luteinizing hormone (LH).

At weekly intervals, the rams were weighed. For the intact rams, testicular weights $(\mathrm{g})$ were estimated using a series of calibrated beads as described and validated by Oldham et al. (1978).

\section{Preparation of hr-inhibin $A$ and vehicle}

The hr-inhibin A, kindly supplied by Biotech Australia Pty Ltd (Sydney, NSW, Australia), was identical to that reported previously by us (Tilbrook et al. 1993a,b) and its biological and physicochemical characteristics have been described previously (Tierney et al. 1990). The hr-inhibin A was originally stored in $\sim 35 \%$ acetonitrile $/ 0 \cdot 1 \%$ trifluroacetic acid at $-70{ }^{\circ} \mathrm{C}$ and each sample was thawed, bovine serum albumin $(0.1 \%$ final concentration) added, the acetonitrile removed by evaporation under nitrogen and the remaining sample gel-filtered (Sephadex G-25, PD 10 columns: Pharmacia, Uppsala, Sweden) in Dulbecco's phosphate buffer, $\mathrm{pH} 7 \cdot 2$. Aliquots of the inhibin fraction were stored at $-70{ }^{\circ} \mathrm{C}$ and were diluted in sterile saline/hr-inhibin $\mathrm{A}(0.9 \% \mathrm{NaCl})$ to the appropriate concentration. The vehicle consisted of appropriate volumes of the phosphate buffer and saline identical to the volumes of hr-inhibin A and saline used in each case.

\section{Radioimmunoassays}

Plasma FSH was measured by radioimmunoassay as described by Bremner et al. (1980) using NIADDKoFSH-RP1 as standard. Nine assays were conducted with a mean ( \pm S.E.M.) assay sensitivity of $0.18 \pm 0.06 \mathrm{ng} / \mathrm{ml}$.

Plasma concentrations of immunoreactive inhibin were measured in all samples using a double antibody radioimmunoassay based on antiserum (no. 1989) raised against bovine $31 \mathrm{kDa}$ inhibin and using iodinated $31 \mathrm{kDa}$ bovine inhibin as tracer (Robertson et al. 1988). This Monash assay has been validated for measurement of ovine inhibin (Findlay et al. 1990) and cross-reacts 288\% with Pro- $\alpha_{c}$, a product of the $\alpha$-subunit of inhibin (Findlay et al. 1990). There is no significant cross-reactivity with activin-A, transforming growth factor $\beta$, and Müllerian-inhibiting substance. For 16 assays of inhibin, the mean ( \pm s.E.M.) assay sensitivity was $0 \cdot 23 \pm 0.01 \mathrm{ng} / \mathrm{ml}$ with a range of 0.033-0.063 ng/ml.

Since the Monash assay for inhibin described above can measure inhibin $\alpha$-subunit products, as well as inhibin, a subset of samples was assayed for inhibin using a two-site immunoassay specific for dimeric inhibin A (Groome \& O'Brien 1993, Groome et al. 1996). The concentrations measured using this assay were used to validate the calculations of the half-life of inhibin that were made from concentrations measured using the Monash assay. For intact and castrated rams treated with hr-inhibin A, 
samples at 6,12 and 18 months of age were assayed for inhibin by the procedure described by Groome et al. (1996) using WHO 91/624 hr-inhibin A (1000 pg/ml$3.91 \mathrm{pg} / \mathrm{ml}$ ) as the standard. For 10 assays, the intra- and inter-plate coefficient of variation values were 6.45 and $9 \cdot 43$ respectively.

A radioimmunoassay, described by Lee et al. (1976) and using NIH LH S18 as the standard was used to measure the plasma concentrations of LH. Three assays were conducted with a mean ( \pm S.E.M.) assay sensitivity of $0.58 \pm 0.08 \mathrm{ng} / \mathrm{ml}$.

\section{Half-life analysis}

To derive an estimate of the half-life of inhibin, a single order exponential decay curve was fitted to plasma concentrations of inhibin for each animal that was injected with hr-inhibin A. For all ages studied these estimations of half-life were made from the plasma concentrations of inhibin that were measured using the Monash assay (Robertson et al. 1988, Findlay et al. 1990). At 6, 12 and 18 months of age, the half-life of inhibin was also estimated from the plasma concentrations of inhibin that were measured using the dimer-specific assay (Groome \& O'Brien 1993, Groome et al. 1996). For each animal the values of inhibin estimated by the exponential decay curve were compared with the concentrations of inhibin using paired $t$-tests. The parameters of the estimated and actual curve were also compared using paired $t$-tests. For all animals there were no significant differences between the values and parameters of the actual and fitted curves. This was the case using values from both assays. Therefore, the estimates of half-life of inhibin derived from this approach were considered to represent the disappearance of hrinhibin A from the blood following injection of hr-inhibin A. Moreover, when the half-lives of inhibin calculated from measurements of inhibin using the two inhibin assays were compared at 6,12 and 18 months of age using repeated measures analysis of variance there were no significant differences between these estimations at each age. This ensured estimations of the half-life of inhibin using the Monash assay were representative of the disappearance of inhibin A from the circulation in rams following an injection of hr-inhibin A.

\section{Statistical analyses}

The parameters in this experiment were analysed by repeated measures analysis of variance. Specifically, the plasma concentrations of FSH, inhibin and LH before, and over $24 \mathrm{~h}$ after the injection of vehicle or hr-inhibin A at each age were compared. Analysis was also conducted on the plasma concentrations of FSH when expressed as a percentage of the mean of the concentrations before injection of vehicle or hr-inhibin A (pre-treatment). To obtain an estimation of the pattern of secretion of FSH, inhibin and LH with age, the mean concentrations of these hormones before injection (pre-treatment) of vehicle or hr-inhibin A were compared between treatments at each age. Comparisons of the mean half-lives of inhibin following injection of hr-inhibin $\mathrm{A}$ in castrated and intact rams at each age were also made. Within the sampling regimen used in this experiment, the maximal concentration of inhibin following injection of hr-inhibin A occurred $1 \mathrm{~min}$ after injection and this peak value was compared between treatments at each age. Finally, the liveweight and estimated testicular weights of the rams were also compared between treatments at each age. For Figs 1-4, betweensubject standard errors are shown on the figures and the within-subject standard errors are stated in the legend of each figure. We have presented the within-subject standard errors because these are relevant to the repeated measures analysis of variance. For all parameters analysed in this experiment, paired comparisons were made using least significant differences.

\section{Results}

Pre-treatment plasma concentrations of FSH and immunoreactive inhibin from 1 to 18 months of age

Within intact and castrated groups, the pre-treatment concentrations of FSH from 1 to 18 months of age did not differ significantly between animals that were allocated to vehicle or hr-inhibin A treatment groups at each sampling period. Nevertheless, the pre-treatment plasma concentrations of FSH were significantly $(P<0 \cdot 01)$ higher in castrated rams than in intact rams at all ages (Fig. 1). Furthermore, the plasma concentrations of FSH varied significantly over age in both intact and castrated rams.

For intact rams, the plasma concentrations of FSH were significantly $(P<0 \cdot 01)$ higher at 1 month of age than at all other ages (Fig. 1) and decreased from 1 to 12 months of age with a nadir at 9 months subsequently increasing between 12 and 18 months. (Fig. 1).

At all ages, the plasma concentrations of FSH in the castrated rams were significantly higher $(P<0 \cdot 05)$ than those in intact rams. For the castrated rams the plasma concentrations of FSH rose progressively and significantly from 1 month of age to peak at 9 months of age, decreasing significantly $(P<0 \cdot 01)$ at 12 months before increasing significantly $(P<0 \cdot 01)$ again from 12 to 18 months (Fig. 1).

The pre-treatment concentrations of inhibin were not significantly different at any age between rams, intact or castrated, that were allocated to the vehicle or hr-inhibin A groups. At all ages, however, the pre-treatment concentrations of inhibin in intact rams were significantly $(P<0 \cdot 01)$ higher than those in castrated rams. In intact rams the concentrations of inhibin also varied significantly $(P<0 \cdot 01)$ over age but there was no significant variation in the concentrations of inhibin over age in castrated rams (Fig. 1). 


\section{a) Intact rams}

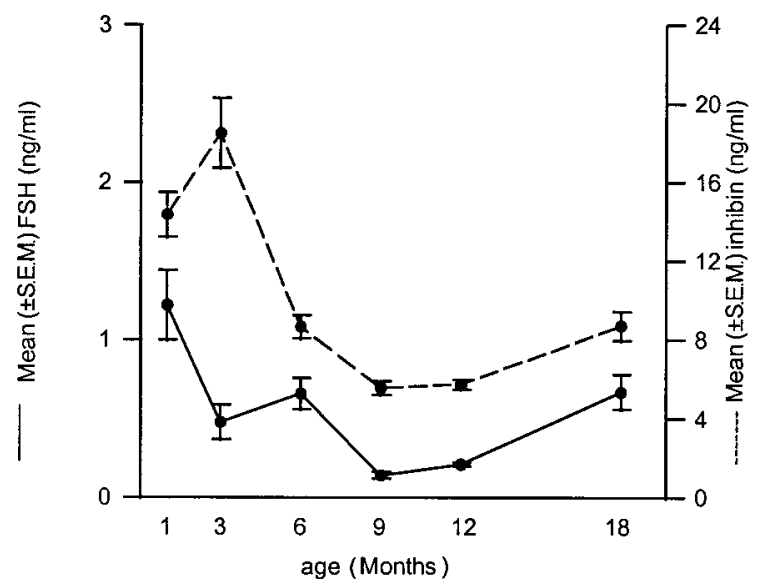

b) Castrated rams

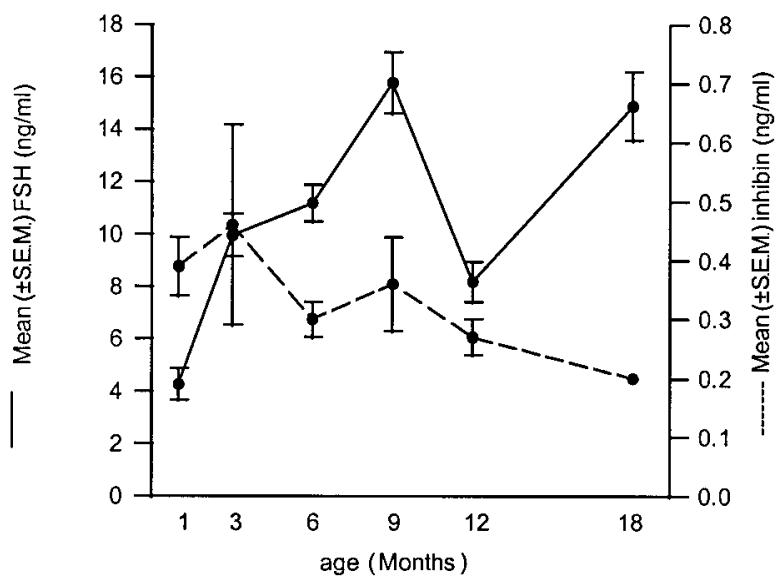

Figure 1 Mean ( \pm S.E.M.) plasma concentrations $(\mathrm{ng} / \mathrm{ml})$ of $\mathrm{FSH}$ and inhibin in all intact (a) and castrated (b) rams at 1, 3, 6, 9, 12 and 18 months of age. The plasma concentrations of FSH were significantly $(P<0 \cdot 01)$ higher in castrated rams than in intact rams while the plasma concentrations of inhibin were higher $(P<0 \cdot 01)$ in intact than in castrated rams. Plasma concentrations of FSH and inhibin in intact rams, and FSH in castrated rams, varied with age $(P<0.01)$ but plasma concentrations of inhibin in castrated rams did not change significantly with age. The repeated measures ANOVA used within-subject standard errors to compare across ages. For the intact rams the within-subject standard errors were $0 \cdot 14$ for $\mathrm{FSH}$ and 1.17 for inhibin and for the castrated rams these were $1 \cdot 24$ for $\mathrm{FSH}$ and $0 \cdot 10$ for inhibin.

In intact rams the mean pre-treatment plasma concentrations of inhibin increased significantly $(P<0 \cdot 05)$ from 1 to 3 months of age then decreased significantly $(P<0 \cdot 01)$ from 3 to 6 months of age (Fig. 1) and did not change significantly from 6 to 18 months of age. The plasma concentrations of inhibin at 1 month of age were significantly $(P<0 \cdot 01)$ higher than at 6, 9, 12 and 18 months of age (Fig. 1).

Effect of treatment with hr-inhibin A or vehicle on plasma concentrations of FSH

There were no significant changes in the plasma concentrations of FSH following injection of vehicle into castrated or intact rams at any age. In intact rams, the plasma concentrations of FSH were reduced at all ages except 9 months following treatment with hr-inhibin A (Fig. 2), with maximal suppression $(P<0 \cdot 01)$ occurring $6 \mathrm{~h}$ after injection. The magnitude of this suppression in FSH $6 \mathrm{~h}$ after injection at 12 months of age was significantly $(P<0 \cdot 01)$ greater than at 1,3 and 9 months of age, but there were no other differences (Fig. 3).

In castrated rams, the plasma concentrations of FSH were decreased following injection of hr-inhibin A at all ages and, similarly to the intact rams, the maximal suppression $(P<0 \cdot 01)$ in FSH concentrations occurred $6 \mathrm{~h}$ after injection of hr-inhibin A (Fig. 2). In contrast to the intact rams, however, there were no significant effects of age on the magnitude of the suppression in plasma concentrations of FSH in castrated rams which occurred $6 \mathrm{~h}$ after injection of hr-inhibin A (Fig. 3). Nevertheless, in the castrated rams, there were apparent age effects on the time following injection of hr-inhibin A that plasma concentrations of FSH were first significantly lower than pre-treatment values (Fig. 2). A significant suppression in FSH occurred within 1 min $(P<0 \cdot 01)$ of injection of hr-inhibin A at 12 months of age, 30 min at 9 months of age, $1 \mathrm{~h}(P<0 \cdot 05)$ at 18 months of age and $3 \mathrm{~h}(P<0 \cdot 01)$ at 6 months of age. At all these ages, the plasma concentrations of FSH remained significantly suppressed thereafter to reach maximal suppression at $6 \mathrm{~h}$. At 1 and 3 months of age, however, a significant reduction in the concentrations of FSH was not evident until $6 \mathrm{~h}$ after the injection of hr-inhibin A (Fig. 2).

In addition to changes with age in the rapidity of response in suppression of FSH in castrated rams following injection of hr-inhibin A, there were effects of age on the period that FSH concentrations remained significantly lower than pre-treatment values. At 1 and 6 months of age, FSH concentrations returned to pre-treatment concentrations by $12 \mathrm{~h}$ after injection of hr-inhibin A, whereas a prolonged response was noted at 9, 12 and 18 months of age when FSH levels $12 \mathrm{~h}$ after injection were still significantly $(P<0 \cdot 01)$ lower than the pretreatment concentrations. Indeed, at 9 months of age, the plasma concentrations of FSH $24 \mathrm{~h}$ after injection of hr-inhibin A remained significantly $(P<0 \cdot 01)$ lower than pre-treatment concentrations but at the other ages there were no differences between pre-treatment concentrations of FSH and concentrations $24 \mathrm{~h}$ after injections (Fig. 2). 
a) Intact rams
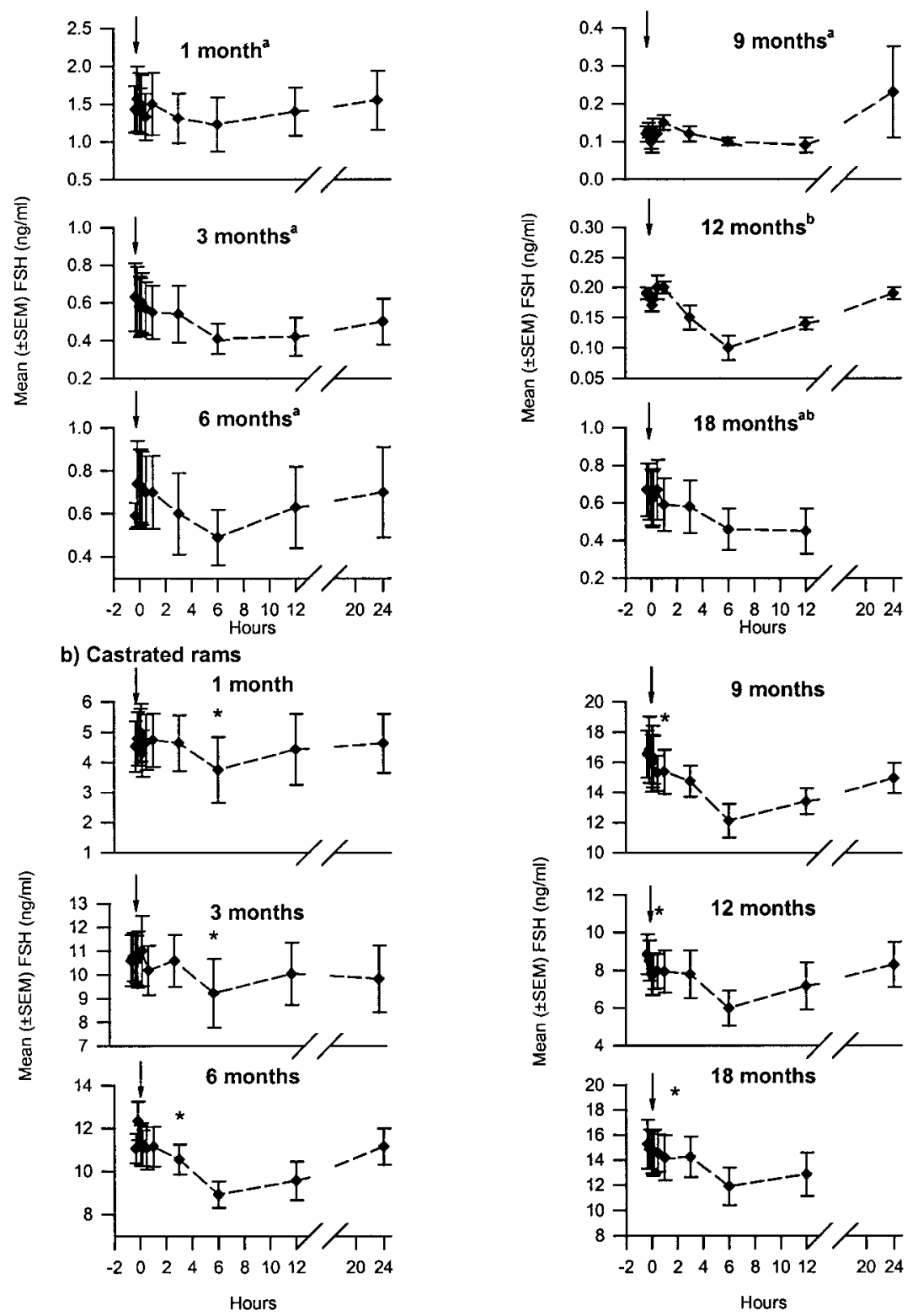

Figure 2 Mean ( \pm S.E.M.) plasma concentrations ( $\mathrm{ng} / \mathrm{ml})$ of FSH in intact (a) and castrated (b) rams before and over $24 \mathrm{~h}$ after injection (indicated by the arrow) of hr-inhibin A at 1, 3, 6, 9, 12 and 18 months of age. For both intact and castrated rams, the maximal suppression in FSH occurred $6 \mathrm{~h}$ after injection of hr-inhibin A. For the intact rams (a), different letters represent differences $(P<0 \cdot 01)$ between ages in the plasma concentrations of FSH $6 \mathrm{~h}$ after injections of the rams with hr-inhibin A. For the castrated rams (b), the asterix indicates the time after injection of hr-inhibin A when plasma concentrations of FSH were significantly $(P<0 \cdot 05)$ lower than pre-treatment concentrations. The within-subject standard errors, which were used in the repeated measures ANOVA to determine differences across ages, were 0.03 for the intact rams and 0.33 for the castrated rams. Vehicle injections had no effects on $\mathrm{FSH}$ in both intact and castrated rams. 


\section{a) Intact rams}
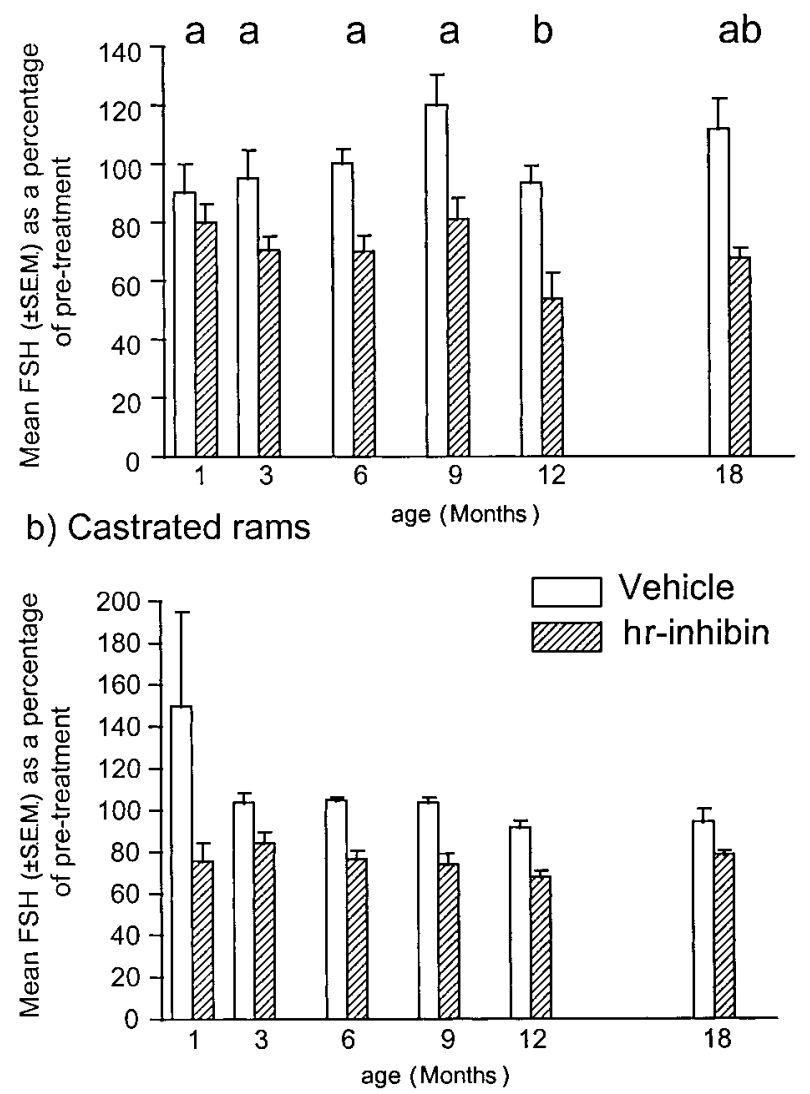

Figure 3 Mean ( \pm S.E.M.) plasma concentrations of FSH $6 \mathrm{~h}$ after injection expressed as a percentage of the pre-treatment values in intact (a) and castrated (b) rams injected with vehicle or hr-inhibin A at 1, 3, 6, 9, 12 and 18 months of age. This represents the time after injection of hr-inhibin A when FSH was maximally suppressed. For the intact rams the maximal suppression in $\mathrm{FSH}$ $6 \mathrm{~h}$ after injection of hr-inhibin A was greatest $(P<0 \cdot 01)$ at 12 months of age and different letters indicate significant $(P<0 \cdot 01)$ differences between ages. For the castrated rams the magnitude of maximal suppression in FSH did not vary with age. There were no differences between castrated and intact rams in the magnitude of maximal suppression of FSH $6 \mathrm{~h}$ after injection of hr-inhibin A. The within-subject standard errors were 7.98 for the intact rams and $5 \cdot 81$ for the castrated rams. Vehicle injections had no effects on $\mathrm{FSH}$.

At each age, the plasma concentrations of FSH in intact rams were always significantly $(P<0.01)$ less than the concentrations in castrated rams. Consequently, even though the plasma concentrations of FSH were suppressed maximally $6 \mathrm{~h}$ after injection of hr-inhibin A, the levels achieved in the castrated rams were significantly $(P<0 \cdot 01)$ greater than the levels in the intact rams. In contrast, the degree of suppression in plasma concentrations of FSH $6 \mathrm{~h}$ after injection of hr-inhibin A was similar in castrated and intact rams (Fig. 3).
Effect of treatment with hr-inhibin $A$ or vehicle on plasma concentrations of $\mathrm{LH}$

At all ages, there were no significant changes in the plasma concentrations of LH following injection of vehicle or hr-inhibin A in intact and castrated rams (data not shown). The plasma concentrations of $\mathrm{LH}$ were higher in castrated rams than in intact rams at 3,6 $(P<0 \cdot 05), 9,12$ and 18 $(P<0 \cdot 01)$ months of age. The concentrations of $\mathrm{LH}$ in the intact rams did not vary significantly with age but in the castrated rams there was a significant age effect $(P<0 \cdot 05)$. In the castrated rams the concentrations of LH increased significantly $(P<0.05)$ from 1 to 3 months of age, was similar at 3 and 6 months of age before increasing $(P<0.01)$ to maximal values at 9 months of age. These concentrations then decreased and were similar at 12 and 18 months of age (data not shown).

Concentrations and estimations of half-life of inhibin following injection of hr-inhibin $A$

From measurements of the plasma concentrations of inhibin using the Monash assay (Robertson et al. 1988, Findlay et al. 1990) injection of hr-inhibin A into intact and castrated rams resulted in a significant $(P<0 \cdot 05)$ increase in the plasma concentrations of inhibin, reaching a maximum within $1 \mathrm{~min}$ of injection and then decreasing rapidly thereafter (data not shown). There were no differences between intact rams and castrated rams in the concentrations of inhibin achieved $1 \mathrm{~min}$ after injection of hr-inhibin A (Table 1).

The plasma concentrations of inhibin measured using the dimer-specific assay for inhibin A (Groome \& O'Brien 1993, Groome et al. 1996) were undetectable prior to injection of hr-inhibin A but, following injection, the pattern of inhibin in the plasma was similar to that observed using the Monash assay, increasing significantly $(P<0 \cdot 05)$ to reach a peak after $1 \mathrm{~min}$, then decreasing rapidly (data not shown). Similarly to measurements made using the Monash assay, the concentrations of inhibin 1 min after injection of hr-inhibin A measured using the dimer-specific assay did not differ between intact and castrated rams at any age (Table 1). Nonetheless, the plasma concentrations of inhibin $1 \mathrm{~min}$ after injection of hr-inhibin A measured using the Monash assay were significantly $(P<0 \cdot 05)$ higher than those measured using the dimer-specific assay.

For both intact and castrated rams, the half-life of inhibin estimated from data collected using the Monash assay varied with age (Table 1). For the intact rams, the estimated half-lives of inhibin at 3 and 6 months of age were significantly $(P<0 \cdot 05)$ longer than at 1,12 and 18 months of age. The half-life of inhibin at 9 months of age was significantly $(P<0 \cdot 05)$ shorter than at 6 months of age but was not significantly different than other ages. For the castrated rams, the mean ( \pm s.E.M.) estimated half-life 
Table 1 Mean ( \pm S.E.M.) half-lives of inhibin $(\mathrm{min})$ and peak plasma concentrations of inhibin $(\mathrm{ng} / \mathrm{ml})$ that occurred 1 min after injection of hr-inhibin A in intact and castrated rams treated with hr-inhibin A. Half-lives (half-life) and peak plasma concentrations of inhibin (peak inhibin) derived from measurements of inhibin using the Monash assay (Robertson et al. 1988, Findlay et al. 1990) are shown for 1, 3, 6, 9, 12 and 18 months of age. Half-lives and peak inhibin concentrations derived from measurements of inhibin using the dimer-specific assay (Groome \& O’Brien 1993, Groome et al. 1996) are shown for 6, 12 and 18 months of age.

\begin{tabular}{|c|c|c|c|c|c|c|c|c|}
\hline & & & Age (month & & & & & \\
\hline & & & 1 & 3 & 6 & 9 & 12 & 18 \\
\hline Half-life (min) & $\begin{array}{l}\text { Assay } \\
\text { Monash }\end{array}$ & $\begin{array}{l}\text { Intact rams } \\
\text { Castrated rams }\end{array}$ & $\begin{array}{l}3 \cdot 5 \pm 0 \cdot 7^{x} \\
5 \cdot 6 \pm 0 \cdot 3^{a}\end{array}$ & $\begin{array}{r}12 \cdot 7 \pm 3 \cdot 1^{y} \\
6 \cdot 3 \pm 1 \cdot 5^{a}\end{array}$ & $\begin{array}{r}11 \cdot 4 \pm 3 \cdot 4^{y} \\
5 \cdot 8 \pm 0 \cdot 6^{a}\end{array}$ & $\begin{array}{l}7 \cdot 8 \pm 0 \cdot 6^{\mathrm{x}} \\
4 \cdot 3 \pm 0 \cdot 8^{\mathrm{a}}\end{array}$ & $\begin{array}{l}5 \cdot 6 \pm 2 \cdot 0^{\mathrm{x}} \\
2 \cdot 8 \pm 0 \cdot 4^{\mathrm{b}}\end{array}$ & $\begin{array}{l}2 \cdot 3 \pm 0 \cdot 2^{x} \\
1 \cdot 7 \pm 0 \cdot 3^{b}\end{array}$ \\
\hline & Dimer-specific & $\begin{array}{l}\text { Intact rams } \\
\text { Castrated rams }\end{array}$ & - & - & $\begin{array}{l}9 \cdot 2 \pm 1 \cdot 4^{y} \\
6 \cdot 0 \pm 0 \cdot 6^{a}\end{array}$ & - & $\begin{array}{l}4 \cdot 3 \pm 1 \cdot 2^{x} \\
4 \cdot 3 \pm 1 \cdot 2^{b}\end{array}$ & $\begin{array}{l}1 \cdot 9 \pm 0 \cdot 2^{x} \\
2 \cdot 8 \pm 0 \cdot 7^{b}\end{array}$ \\
\hline Peak inhibin (ng/ml) & Monash & $\begin{array}{l}\text { Intact rams } \\
\text { Castrated rams }\end{array}$ & $\begin{array}{r}15 \cdot 9 \pm 2 \cdot 3 \\
6 \cdot 2 \pm 0 \cdot 3\end{array}$ & $\begin{array}{r}17 \cdot 9 \pm 0 \cdot 4 \\
5 \cdot 9 \pm 1 \cdot 5\end{array}$ & $\begin{array}{r}13 \cdot 0 \pm 1 \cdot 3 \\
8 \cdot 6 \pm 0 \cdot 9\end{array}$ & $\begin{array}{r}11 \cdot 4 \pm 1 \cdot 0 \\
7 \cdot 9 \pm 2 \cdot 7\end{array}$ & $\begin{array}{l}14 \cdot 6 \pm 3 \cdot 0 \\
18 \cdot 3 \pm 5 \cdot 1\end{array}$ & $\begin{array}{l}49 \cdot 9 \pm 3 \cdot 1^{x} \\
42 \cdot 1 \pm 4 \cdot 2\end{array}$ \\
\hline & $\begin{array}{l}\text { Dimer-specific } \\
\text { Monash }\end{array}$ & $\begin{array}{l}\text { Intact rams } \\
\text { Castrated rams }\end{array}$ & - & - & $\begin{array}{l}5 \cdot 9 \pm 0 \cdot 4 \\
8 \cdot 4 \pm 0 \cdot 6\end{array}$ & - & $\begin{array}{l}11 \cdot 3 \pm 3 \cdot 6 \\
13 \cdot 6 \pm 3 \cdot 0\end{array}$ & $\begin{array}{l}47 \cdot 5 \pm 5 \cdot 4 \\
34 \cdot 1 \pm 4 \cdot 8\end{array}$ \\
\hline
\end{tabular}

For the half-life of inhibin, within rows, different superscripts represent significant differences between means: ${ }^{x, y} P<0 \cdot 01$; ${ }^{a, b} P<0 \cdot 05$. The results did not differ significantly between assays. The half-lives of inhibin in the intact rams at 6 months of age were significantly $(P<0 \cdot 01)$ longer than the half-lives of inhibin in the castrated rams at each age. The peak concentrations of inhibin $1 \mathrm{~min}$ after injection of hr-inhibin A measured by the Monash assay were significantly $(P<0 \cdot 01)$ higher at each age than those measured by the dimer-specific assay. For both assays, there were no differences at any age between intact and castrated rams in peak inhibin.

of inhibin did not differ from 1 to 9 months of age but the half-life declined significantly $(P<0 \cdot 05)$ at 12 and 18 months of age (Table 1).

The estimated mean ( \pm s.E.M.) half-lives of inhibin for the intact rams at 3 and 6 months of age were significantly $(P<0 \cdot 01)$ longer than the estimated half-lives of inhibin for the castrated rams for all ages. Also, the half-life of inhibin for intact rams at 9 months of age was significantly $(P<0 \cdot 05)$ longer than that for the castrated rams at 9 months of age (Table 1$)$. There were no other differences between intact and castrated rams in the half-life of inhibin.

The estimations of half-life of inhibin made using data collected using the dimer-specific assay (Groome \& O’Brien 1993, Groome et al. 1996) did not differ significantly from the estimations made using the Monash assay (Robertson et al. 1988, Findlay et al. 1990) and showed the same variations between 6,12 and 18 months of age in both intact and castrated rams (Table 1).

\section{Testicular weight}

The mean ( \pm s.E.M.) estimated testicular weight $(\mathrm{g})$ of intact rams treated with vehicle or hr-inhibin A (Fig. 4) varied significantly with age $(P<0 \cdot 01)$. The weight of the testes increased from 1 month of age to peak between 7 and 9 months of age before decreasing to plateau from 10 months to the end of the experiment (Fig. 4). The increase in testicular weight was most rapid from about 6 months of age, a time corresponding to about 10 weeks after the summer solstice. Although the testes decreased in weight after having attained maximal weight, testicular weight after 6 months of age was always significantly $(P<0 \cdot 05)$ greater than before 6 months of age. The change in testicular weight with age showed a similar pattern in the rams treated with vehicle or hr-inhibin A but there were differences in the mean testicular weight between treatments. In the rams treated with hr-inhibin A, between 6 and 9 months of age, testicular weight was significantly $(P<0 \cdot 01)$ less than the weight of testes from rams treated with vehicle. However, these differences were lost after 9 months.

\section{Liveweight}

The mean liveweight of all animals increased significantly $(P<0 \cdot 01)$ throughout the experiment and there were no differences between treatment groups. The mean ( \pm s.E.M.) liveweight increased from $8.7 \pm 0.4 \mathrm{~kg}$ at 1 month of age to $47 \cdot 1 \pm 0 \cdot 9 \mathrm{~kg}$ at 18 months of age.

\section{Discussion}

The results of this experiment demonstrate that hr-inhibin A can suppress the secretion of FSH in ram lambs from at least 1 month of age. In both intact and castrated ram lambs at all ages, treatment with hr-inhibin A resulted in a maximal suppression of FSH $6 \mathrm{~h}$ after injection, a time course similar to that found in adult rams (Tilbrook et al. 1993a), ovariectomized ewes (Clarke et al. 1993) and male rats (Carroll et al. 1991, Rivier et al. 1991, Robertson et al. 


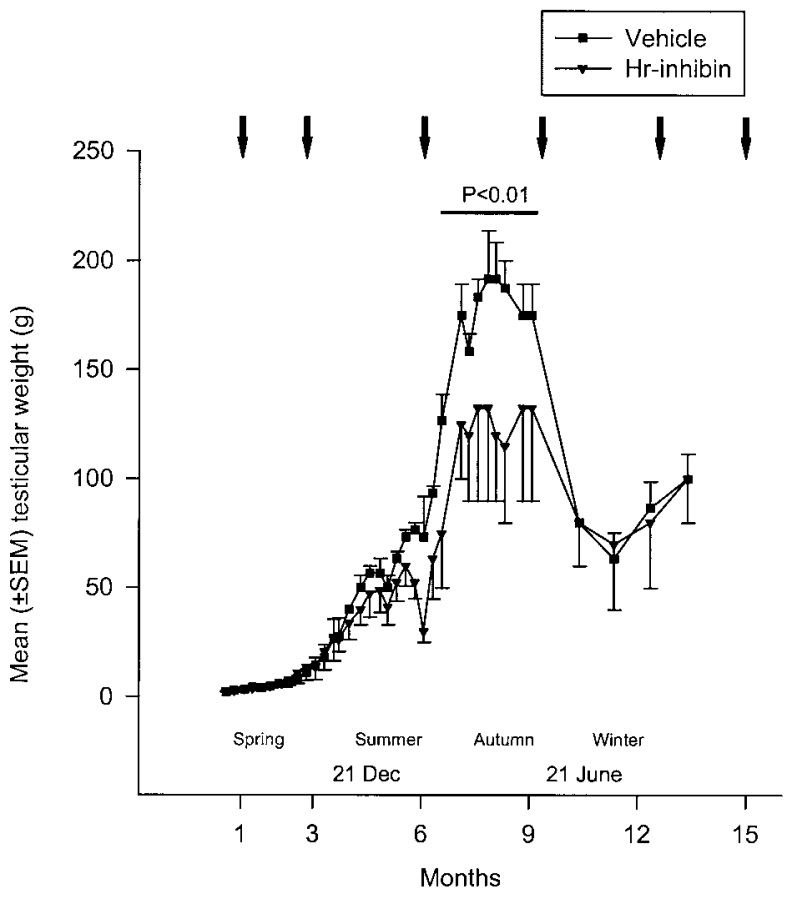

Figure 4 Mean ( \pm S.E.M.) estimated testicular weight $(\mathrm{g})$ in rams treated with vehicle or hr-inhibin A over the course of the experiment. The within-subject standard error was 6.88. Arrows represent the times that the treatment and sampling were undertaken. The seasons of the year and the summer (21 December) and winter (21 June) solstices for the southern hemisphere are indicated. The estimated testicular weight varied significantly with age $(P<0.01)$ increasing from 1 month of age to reach a peak between 7 and 9 months of age. Between 6 and 9 months of age the estimated testicular weight in rams treated with hr-inhibin A was significantly less $(P<0 \cdot 01)$ than in rams treated with vehicle and this period is illustrated by the solid bar on the figure.

1991). Our data suggest that a functional inhibin-feedback system is established at an early age in rams and we found that the responsiveness of the pituitary to the actions of inhibin changed with age and whether the rams were castrated or intact. In the intact rams, the greatest suppression occurred at 12 months of age whereas, in the castrated ram lambs, the maximal suppression in FSH achieved following injection of hr-inhibin A did not vary between ages but there was an age effect on the rapidity and duration of the response. In the castrated rams, the most rapid decrease in plasma concentrations of FSH following injection of hr-inhibin $\mathrm{A}$, and the period when FSH concentrations were suppressed for longest, occurred at 9 and 12 months of age and the rapidity of the response to hr-inhibin A had clearly begun to increase from 6 months of age. It is unclear why the pattern of response of FSH varied with time in the castrated rams. Nevertheless, overall, there were no differences between the intact and castrated rams in the magnitude of the maximal suppression of FSH due to treatment with hr-inhibin A and the suppression in FSH was similar to that obtained in adult rams using an identical dose and treatment regimen of hr-inhibin A (Tilbrook et al. 1993a). This indicates that the pituitary gland of rams had achieved maximal responsiveness to the actions of inhibin by at least 12 months of age which is an age when the intact rams would have attained puberty (Tilbrook et al. 1993c). These findings strongly suggest that the inhibin-feedback system exists from an early age in rams but develops to be maximally effective once puberty has been achieved.

This study demonstrates that there are significant changes in the half-life of an injected dose of inhibin, probably reflecting alterations in clearance rates, that are affected by age and testicular activity. The effects of age are most clearly demonstrated in the castrated rams where the half-life decreased in the older animals (12 and 18 months). Similar findings were noted in the intact rams at these ages. Effectively, the half-life after an intravenous injection of a substance can be used as a crude index of clearance rate. Our estimations of half-life were similar with an assay that can measure both dimeric inhibin and inhibin $\alpha$-subunit products (Robertson et al. 1988, Findlay et al. 1990) and an assay that is dimer-specific (Groome \& O'Brien 1993, Groome et al. 1996) ruling out the possibility that $\alpha$-subunit products, detected by the Monash assay, are responsible for this alteration in clearance rates. The implication of these changes suggest that lower circulating levels of inhibin are achieved at these ages yet no change was found in the capacity to suppress FSH. These data provide evidence that the pituitary is more sensitive to inhibin at these time points. It should be noted that the half-lives are less than those measured in the rat (Robertson et al. 1988), ram (Schanbacher 1988) or man (Ishida et al. 1990) but all of these results were obtained in intact males. The lower half-life and, therefore, the more rapid clearance rate of inhibin in the castrated ram may be a reflection of the absence of the testis. Similar shorter half-lives were also noted in our study in intact rams when testicular weight was reduced reflecting diminished testicular activity due to seasonal influences.

Further evidence that testicular activity can influence the clearance rate of inhibin emerges from the observations that the inhibin half-life was longer in intact rams at 3, 6 and 9 months of age, all of which corresponded to times at which testicular weights were greater than at 12 and 18 months. The decline in estimated testicular weight is a reflection of seasonal breeding patterns in this breed in which testicular weight declines after the winter solstice (Bremner et al. 1984). The cause of the changes in the half-life of an injected dose of inhibin are not known. A decrease in clearance can be achieved if hormones or growth factors are bound to proteins. Our laboratory has shown that inhibin can be bound to the fast-form of a2-macroglobulin (Phillips et al. 1997) and others have shown binding of inhibin to follistatin (Krummen et al. 
1993). No data are available to indicate whether follistatin levels increase during sexual maturation. Nevertheless, $\alpha 2-$ macroglobulin is a product of the Sertoli cell so may respond to the increase in concentrations of $\mathrm{FSH}$ associated with sexual maturation or following the summer solstice and may, therefore, be a potential mediator of these changes in clearance rates of inhibin.

In the intact rams, the plasma concentrations of inhibin during the pre-treatment period also varied with age being highest at the young ages and decreasing during sexual development. This is a similar pattern to that reported previously in rams (Schanbacher 1988, Isaacs et al. 1995) and in bulls (Miyamoto et al. 1989, MacDonald et al. 1991) and male rats (Crofton et al. 1997) but is different to that found in male monkeys (Keeping et al. 1990, Marson et al. 1993) and boys (Burger et al. 1988, Crofton et al. 1997). Nonetheless, a recent study in boys using a specific assay for inhibin B has shown that levels of this hormone are high in the first year of life (Andersson et al. 1997). Clearly, there are species differences in the patterns of secretion of inhibin during sexual development and systematic studies are required to firmly establish the age effects of the actions of inhibin on FSH secretion in other species. Our results illustrate that generalizing about the actions of a hormone based solely from changes in its pattern of secretion can be misleading. Even though the concentrations of inhibin decreased around the time of puberty in rams, the potency of the hr-inhibin A in terms of suppressing the secretion of FSH was greatest at this time. Interestingly, it has also been suggested that the inhibin-feedback system is most important after the onset of puberty in male chimpanzees (Marson et al. 1993) and boys (Crofton et al. 1997) despite the difference in the pattern of secretion of inhibin during sexual development that occurs between these species and rams.

In contrast to the intact rams, plasma concentrations of inhibin were low in castrated rams, did not vary with age and represent the presence of an extratesticular source which may be the adrenal glands (McNeilly et al. 1994). It is possible that these circulating levels represent free $\alpha$-subunit since dimer-specific assays have shown undetectable inhibin levels in the circulation of castrated monkeys (Plant et al. 1997). The higher concentrations of inhibin in the intact rams reflect changes in the testicular secretion of inhibin. The lower concentrations of FSH in the intact rams result from the negative feedback actions of endogenous inhibin (Schanbacher 1988, Mckeown et al. 1997) and testosterone (Crim \& Geschwind 1972, Foster et al. 1972, Olster \& Foster 1986). In ram lambs, it has been shown that secretion of FSH and LH increases during early pubertal development and then decreases as development continues (Lee et al. 1976, Foster et al. 1978, Wilson \& Lapwood 1979) and the current data concur with these earlier studies. That the plasma concentrations of LH and FSH in castrated rams also varied with age suggests that changes in the secretion of the gonadotrophins can occur independently of the hormones secreted by the testes and this has been demonstrated previously. In agonadal children (Conte et al. 1975, Reiter \& Grumbach 1981) and in castrated male Rhesus monkeys (Plant 1980), the FSH and LH levels were high for 2 years post-partum, then declined and rose again about the time puberty would have occurred. A similar phase of elevated FSH secretion was noted in castrated rams at 5 weeks of age (Olster \& Foster 1986). In addition to the changes in the circulating gonadotrophin levels that can occur in the absence of testes, our experiment also shows that there are testicular-independent changes in the responsiveness of the pituitary to the actions of inhibin and in the clearance rate of inhibin in rams during sexual development.

The intact rams treated with hr-inhibin A had a lower estimated testicular weight than the control rams during a period of rapid testicular growth that coincided with the onset of puberty and the shortening of photoperiod normally causing seasonal testicular stimulation. This implies that treatment with hr-inhibin A reduced the secretion of FSH at a critical stage for the development of the testes. The ability of a single injection of hr-inhibin A, which reduces plasma FSH levels for $12-24 \mathrm{~h}$ at no more than three time points during testicular maturation, to cause an approximate $30 \%$ decrease in testicular weight can only be described as surprising. It points to the remarkable sensitivity of the testis during this phase to FSH or alternatively suggests that the exposure of the testis to inhibin directly influences testicular growth. It has been clearly shown that normal testicular development in rams is dependent on the gonadotrophins (Courot 1967, Courot \& Ortavant 1981, Jeffcoate et al. 1982, Tilbrook et al. 1993c). The results of the current experiment specifically illustrate the importance of FSH for testicular development because only $\mathrm{FSH}$, and not $\mathrm{LH}$, was reduced following treatment with hr-inhibin A. Moreover, the repeated response to a human protein suggests that antibody production does not limit the action of inhibin. It is unclear from our study whether the treatment induces a permanent change in the capacity of the testis as we did not take the rams through a further breeding cycle. Further studies are required to elucidate these issues.

In summary, our results show that inhibin is capable of suppressing the secretion of FSH in rams from as early as 1 month of age. Furthermore, there are changes with age in the responsiveness of the pituitary gland to the actions of inhibin, the clearance of inhibin and the testicular secretion and circulating concentrations of inhibin. The pituitary appears to be maximally responsive to the actions of inhibin by at least 12 months of age which is when the clearance of inhibin from the blood is also maximal. At this stage of development, the circulating levels of inhibin are minimal. We conclude that the inhibin-feedback system is fully developed in time to exert tight control over the secretion of FSH around the time of puberty in rams. In contrast, inhibin does not affect the secretion of $\mathrm{LH}$ in rams from 1 to 18 months of age. 


\section{Acknowledgements}

We thank Bruce Doughton, Alison Skinner, Maree Purdon, Doug Kerton, Paul Weston, Julie Muir, Tony Pisano, Tina Ambrose and Michelle Serapiglia for technical assistance. We also thank David Caddy for advice on the statistical analysis of the data. This work was funded by the National Health and Medical Research Council of Australia.

\section{References}

Al-Obaidi SAR, Bindon BM, Hillard MA \& O'Shea T 1987 Reproductive characteristics of lambs actively immunized early in life with inhibin-enriched preparations from follicular fluid of cows. Journal of Reproduction and Fertility 81 403-414.

Andersson AM, Juul A, Peterson JH, Groome NP \& Skakkebaek NE 1997 Serum inhibin B in healthy pubertal and adolescent boys: relation to age, stage of puberty, and follicle-stimulating hormone, luteinizing hormone, testosterone, and estradiol levels. Journal of Clinical Endocrinology and Metabolism 82 3976-3981.

Attardi B, Marshall GR, Zorub DS, Winters SJ, Miklos J \& Plant TM 1992 Effects of orchidectomy on gonadotropin and inhibin subunit messenger ribonucleic acids in the pituitary of the Rhesus monkey (Macaca mulatta). Endocrinology 130 1238-1244.

Bremner WJ, Findlay JK, Lee VWK, de Kretser DM \& Cumming IA 1980 Feedback effects of the testis on pituitary responsiveness to luteinizing hormone-releasing hormone infusions in the ram. Endocrinology 106 329-336.

Bremner WJ, Cumming IA, Winfield CG, de Kretser DM \& Galloway DB 1984 A study of the reproductive performance of mature Romney and Merino rams throughout the year. In Reproduction in Sheep, vol 1, pp 16-17. Eds DR Lindsay \& DT Pearce. Canberra: Australian Academy of Science and Australian Wool Corporation.

Burger HG, McLachlan RI, Bangah M, Quigg H, Findlay JK, Robertson DM, de Kretser DM, Warne GL, Werther GA, Hudson IL, Cook JJ, Fiedler R, Greco S, Yong ABW \& Smith P 1988 Serum inhibin concentrations rise throughout normal male and female puberty. Journal of Clinical Endocrinology and Metabolism 67 689-694

Carroll RS, Kowash PM, Lofgren JA, Schwall RH \& Chin WW 1991 In vivo regulation of FSH synthesis by inhibin and activin. Endocrinology 129 3299-3304.

Clarke IJ, Rao A, Fallest PC \& Shupnik MA 1993 Transcription rate of the $\mathrm{FSHb}$ gene is reduced by inhibin in sheep but this does not fully explain the decrease in mRNA. Molecular and Cellular Endocrinology 91 211-216.

Conte FE, Grumbach MM \& Kaplan SL 1975 A diphasic pattern of gonadotropin secretion in patients with the syndrome gonadal dysgenesis. Journal of Clinical Endocrinology and Metabolism $\mathbf{4 0}$ 670-674.

Courot M 1967 Endocrine control of the supporting and germ cells of the impuberal testis. Journal of Reproduction and Fertility 2 89-101.

Courot M \& Ortavant R 1981 Endocrine control of spermatogenesis in the ram. Journal of Reproduction and Fertility 30 47-60.

Crim LW \& Geschwind II 1972 Patterns of FSH and LH secretion in the developing ram: the influence of castration and replacement therapy with testosterone propionate. Biology of Reproduction 7 $47-54$.

Crofton PM, Illingworth PJ, Groome NP, Stirling HF, Swanston I, Gow S, Wu FCW, Mcneilly A \& Kelnar CJH 1997 Changes in dimeric inhibin $\mathrm{A}$ and $\mathrm{B}$ during normal early puberty in boys and girls. Clinical Endocrinology 97 109-114.
Dubey AK, Zeleznik AJ \& Plant TM 1987 In the Rhesus monkey (Macaca mulatta), the negative feedback regulation of follicle stimulating hormone secretion by an action of testicular hormone directly at the level of the anterior pituitary gland cannot be accounted for by either testosterone or estradiol. Endocrinology 121 2229-2237.

Findlay JK, Clarke IJ \& Robertson DM 1990 Inhibin concentrations in ovarian and jugular venous plasma and the relationship of inhibin with follicle-stimulating hormone and luteinizing hormone during the ovine estrous cycle. Endocrinology 126 528-535.

Foster DL, Cook B \& Nalbandov AV 1972 Regulation of luteinizing hormone (LH) in the fetal and neonatal lamb: effect of castration during the early postnatal period on levels of $\mathrm{LH}$ in sera and pituitaries of neonatal lambs. Biology of Reproduction 6 253-257.

Foster DL, Mickelson IH, Ryan KD, Coon GA, Drongowski RA \& Holt JA 1978 Ontogeny of pulsatile luteinizing hormone and testosterone secretion in male lambs. Endocrinology 102 1137-1146.

Groome N \& O’Brien M 1993 Immunoassays for inhibin and its subunits. Further applications of the synthetic peptide approach. Journal of Immunological Methods 165 167-176.

Groome NP, Illingworth PJ, O'Brien M, Pai R, Rodger FE, Mather JP \& McNeilly AS 1996 Measurement of dimeric inhibin B throughout the human menstrual cycle. Journal of Clinical Endocrinology and Metabolism 81 1401-1405.

Isaacs KL, McNatty KP, Condell L, Shaw L, Heath DA, Hudson NL, Littlejohn RP \& McLeod BJ 1995 Plasma FSH, LH, immunoreactive inhibin concentrations in $\mathrm{Fec}(\mathrm{B}) / \mathrm{Fec}(\mathrm{B})$ and $\mathrm{Fec}(+) / \mathrm{Fec}(+)$ Booroola ewes and rams from birth to 12 months of age. Journal of Reproduction and Fertility 103 89-97.

Ishida $\mathrm{H}$, Tashiro $\mathrm{H}$, Watanabe $\mathrm{M}$, Fujii N, Yoshida H, Imamura K, Minowada S, Shinohara M, Fukutani K, Aso Y \& de Kretser DM 1990 Measurement of inhibin concentrations in men: study of changes after castration and comparison with androgen levels in testicular tissue, spermatic venous blood, and peripheral venous blood. Journal of Clinical Endocrinology and Metabolism 70 1019-1022.

Jeffcoate IA, Lucas JMS \& Crighton DB 1982 Effects of active immunization of ram lambs and bull calves against synthetic luteinizing hormone releasing hormone. Theriogenology 18 65-77.

Keeping HS, Winters SJ, Attardi B \& Troen P 1990 Developmental changes in testicular inhibin and androgen-binding protein during sexual maturation in the cynomolgus monkey, Macaca fascicularis. Endocrinology 126 2858-2867.

Krummen LA, Woodruff TK, DeGuzman G, Cox ET, Cossum P \& Mather JP 1993 Identification and charaterization of binding proteins for inhibin and activin in human serum and follicular fluids. Endocrinology 132 431-443.

Lee VWK, Cumming IA, de Kretser DM, Findlay JK, Hudson B \& Keogh EJ 1976 Regulation of gonadotrophin secretion in rams from birth to sexual maturity. I. Plasma LH, FSH and testosterone levels. Journal of Reproduction and Fertility 46 1-6.

MacDonald RD, Deaver DR \& Schanbacher BD 1991 Prepubertal changes in plasma FSH and inhibin in Holstein bull calves: responses to castration and (or) estradiol. Journal of Animal Science 69 276-282.

McKeown RM, O'Callaghan D, Roche JF \& Boland MP 1997 Effect of immunization of rams against bovine inhibin $\alpha 1-26$ on semen characteristics, scrotal size, FSH, LH and testosterone concentrations. Journal of Reproduction and Fertility 109 237-245.

McNeilly AS, Brooks AN, Baxter G \& Webb R. 1994 Sheep adrenal inhibin. In Frontiers in Endocrinology: Inhibin and Inhibin-Related Proteins, pp 261-269. Eds HG Burger, J Findlay, D Robertson, D de Kretser \& F Petraglia. Rome: Ares-Serono Symposia Publications.

Majumdar SS, Mikuma N, Ishwad PC, Winters SJ, Attardi BJ, Perera AD \& Plant TM 1995 Replacement with recombinant human inhibin immediately after orchidectomy in the hypophysiotropically 
clamped male Rhesus monkey (Macaca mulatta) maintains folliclestimulating hormone (FSH) secretion and FSH-beta messenger ribonucleic acid levels at precastration values. Endocrinology 136 1969-1977.

Marson J, Fraser HM, Wickings EJ, Cooper RW, Jouannet P \& Meuris S 1993 Puberty in the male chimpanzee: time-related variations in circulating inhibin. Biology of Reproduction 48 490-494.

Martin TL, Williams GL, Lunstra DD \& Ireland JJ 1991 Immunoneutralization of inhibin modifies hormone secretion and sperm production in bulls. Biology of Reproduction 45 73-77.

Medhamurthy R, Abeyawardene SA, Culler MD, Negro-Vilar A \& Plant TM 1990 Immunoneutralization of circulating inhibin in the hypophysiotropically clamped male Rhesus monkey (Macaca mulatta) results in a selective hypersecretion of follicle-stimulating hormone. Endocrinology 126 2116-2124.

Medhamurthy R, Culler MD, Gay VL, Negro-Vilar A \& Plant TM 1991 Evidence that inhibin plays a major role in the regulation of follicle-stimulating hormone secretion in the fully adult male Rhesus monkey (Macaca mulatta). Endocrinology 129 389-395.

Miyamoto A, Umezu M, Ishii S, Furusawa T, Masaki J, Hasegawa Y \& Ohta M 1989 Serum inhibin, FSH, LH and testosterone levels and testicular inhibin content in beef bulls from birth to puberty. Animal Reproduction Science 20 165-178.

Oldham CM, Adams NR, Gherardi PB, Lindsay DR \& Mackintosh JB 1978 The influence of level of feed intake on sperm-producing capacity of testicular tissue in the ram. Australian Journal of Agricultural Research 29 173-179.

Olster DH \& Foster DL 1986 Control of gonadotropin secretion in the male during puberty: a decrease in response to steroid inhibitory feedback in the absence of an increase in steroidindependent drive in the sheep. Endocrinology 118 2225-2234.

Phillips DJ, McFarlane JR, Hearn MTW \& de Kretser DM 1997 Inhibin, actvin and follistatin bind preferentially to the transformed species of $\alpha 2$ macroglobulin. Journal of Endocrinology 155 65-71.

Plant TM 1980 The effects of neonatal orchidectomy on the developmental pattern of gonadotropin secretion in the male Rhesus monkey (Macaca mulatta). Endocrinology 106 1451-1454.

Plant TM, Padmanabhan V, Ramaswamy S, McConnell DS, Winters SJ, Groome N, Midgley ARJ \& McNeilly AS 1997 Circulating concentrations of dimeric inhibin A and B in the male Rhesus monkey (Macaca mulatta). Journal of Clinical Endocrinology and Metabolism 82 2617-2621.

Reiter EO \& Grumbach MM 1981 Neuroendocrine control mechanisms and the onset of puberty. Annual Review of Physiology 44 595-613.
Rivier C, Corrigan A \& Vale W 1991 Effect of recombinant human inhibin on gonadotropin secretion by the male rat. Endocrinology 129 2155-2159.

Robertson DM, Hayward S, Irby D, Jacobsen J, Clarke L, McLachlan RI \& de Kretser DM 1988 Radioimmunoassay of rat serum inhibin: changes after PMSG stimulation and gonadectomy. Molecular and Cellular Endocrinology 58 1-8.

Robertson DM, Prisk M, McMaster JW, Irby DC, Findlay JK \& de Kretser DM 1991 Serum FSH-suppressing activity of human recombinant inhibin A in male and female rats. Journal of Reproduction and Fertility 91 321-328.

Schanbacher BD 1988 Radioimmunoassay of inhibin: serum responses to unilateral and bilateral orchidectomy. Endocrinology 123 2323-2330.

Schanbacher BD 1991 Pituitary and testicular responses of beef bulls to active immunization against inhibin alpha. Journal of Animal Science 69 252-257.

Tierney ML, Goss NH, Tomkins SM, Kerr DB, Pitt DE, Forage RG, Robertson DM, Hearn MTW \& de Kretser DM 1990

Physicochemical and biological characterization of recombinant human inhibin A. Endocrinology 126 3268-3270.

Tilbrook AJ, de Kretser DM \& Clarke IJ 1993a Human recombinant inhibin A and testosterone act directly at the pituitary to suppress plasma concentrations of FSH in castrated rams. Journal of Endocrinology 138 181-189.

Tilbrook AJ, de Kretser DM \& Clarke IJ 1993 b Human recombinant inhibin A suppresses plasma follicle stimulating hormone to intact levels but has no effect on luteinizing hormone in castrated rams. Biology of Reproduction 49 779-788.

Tilbrook AJ, Galloway DB, Williams AH \& Clarke IJ 1993 c Treatment of young rams with an agonist of GnRH delays reproductive development. Hormones and Behavior 27 5-28.

Wilson PR \& Lapwood KR 1979 Studies of reproductive development in Romney rams: I. basal levels and plasma profiles of $\mathrm{LH}$, testosterone and prolactin. Biology of Reproduction $\mathbf{2 0}$ 965-970.

Wreford NG, O'Conner AE \& de Kretser DM 1994 Gonadotropinsuppressing activity of human recombinant inhibin in the male rat is age dependent. Biology of Reproduction 50 1066-1071.

Received 21 July 1998

Revised manuscript received 4 November 1998 Accepted 3 December 1998 